\title{
Comparison of Fish, Macroinvertebrates and Diatom Communities in Response to Environmental Variation in the Wei River Basin, China
}

\author{
Linfei Liu ${ }^{1,2,3} \mathbb{D}$, Zongxue $\mathrm{Xu}{ }^{1,2, *}$, Fan Yang ${ }^{3,4}$, Xuwang Yin ${ }^{5}$, Wei $\mathrm{Wu}^{6}$ and Jisheng $\mathrm{Li}^{3}$ \\ College of Water Sciences, Beijing Normal University, Beijing 100875, China; liulinfei@mail.bnu.edu.cn \\ 2 Beijing Key Laboratory of Urban Hydrological Cycle and Sponge City Technology, Beijing 100875, China \\ 3 Sericultural Research Institute, Chengde Medical University, Chengde 067000, China; \\ fan_yang@cdmc.edu.cn (F.Y.); jshlee@163.com (J.L.) \\ 4 College of Chemistry and Life Sciences, Chifeng University, Chifeng 024000, China \\ 5 College of Fisheries and Life Science, Dalian Ocean University, Dalian 116023, China; \\ yinxuwang@dlou.edu.cn \\ 6 School of Resources and Environment, University of Jinan, Jinan 250022, China; stu_wuw@ujn.edu.cn \\ * Correspondence: zongxuexu@vip.sina.com
}

Received: 7 October 2020; Accepted: 1 December 2020; Published: 4 December 2020

check for updates

\begin{abstract}
Land use changes usually lead to the deterioration of freshwater ecosystems and reduced biodiversity. Aquatic organisms are considered valuable indicators for reflecting the conditions of freshwater ecosystems. Understanding the relationship between organisms and land use type, as well as physiochemical conditions, is beneficial for the management, monitoring and restoration of aquatic ecosystems. In this study, fish, macroinvertebrates, and diatoms were investigated at 60 sampling sites in the Wei River basin from October 2012 to April 2013 to determine the relationships between the environment and aquatic organisms. The richness, abundance, Shannon diversity, evenness, Margalef diversity, and Simpson diversity were selected as biological indices for analyzing the correlation between these communities and environmental variables according to Pearson's coefficient. Canonical correspondence analysis (CCA) was used to analyze the relationship between the biotic communities and environmental variables. The results showed that three diatom indices were weakly correlated with chemical oxygen demand (COD), qualitative Habitat Evaluation Index (QH), and dissolved oxygen (DO). Four macroinvertebrate indices were associated with total phosphorus (TP) while total nitrogen (TN), and agricultural land (AL) had a significant influence on assemblages, suggesting that macroinvertebrates could respond to nutrient levels in the Wei River basin. All land use types had a strong effect on fish indices except $\mathrm{AL}$, indicating that fish would be better used as indicators of spatial changes in the aquatic ecosystem. In conclusion, fish and macroinvertebrates have the potential for use in routine monitoring programs in the Wei River basin.
\end{abstract}

Keywords: land use; fish; macroinvertebrate; diatom; Wei River basin; correspondence analysis

\section{Introduction}

The effects of land use change on aquatic biotic communities have been widely demonstrated by ecologists throughout the world [1-4] Land use changes have resulted in strong disadvantages to the maintenance of the ecological integrity of river systems [5-7]. Urbanization, agriculturalization, industrialization, and commercialization has become more prevalent with the rapid development of society and economy and the rapid growth of the population [8-10] Much of the forest, grass, and other natural vegetation cover has been replaced with urban land. This may destroy the equilibrium of the primary ecosystem and alter the biotic community structure. 
The demands of human development result in the exploitation of large amounts of natural land through processes such as deforestation. Soil erosion tends to increase with the decrease in forestland, which results in increases in sandy concentrations; nutrients such as nitrogen, phosphorus, and ammonia; heavy metal ions; organic contaminants and toxic pollutants, which flow into rivers via storm runoff $[11,12]$. Moreover, habitat diversity decreases and fine sediments replace cobblestone sediments, which adversely impact fish spawning and diatom or macroinvertebrate attachment [6]. Meanwhile, sewage from agriculture, industry, and domestic sources discharges into rivers with the increase in agriculturalization and urbanization, also reducing water quality [13]. Another effect of land use change on aquatic organisms is through hydraulic engineering; for example, the construction of dams and reservoirs and the channelization and realignment of rivers to satisfy agricultural irrigation demands, ensuring adequate water for industrial and domestic activities [14]. All of these changes have strong impacts on the original ecological environment.

Aquatic organisms play important roles in freshwater ecosystems and can indicate variations in ecosystem conditions through their richness, abundance, diversity, composition, or other biological indices [15-17]. Fish are relatively higher-order organisms and represent an important component of the aquatic ecosystem. Because of their strong mobilities and longer growing periods, fish can reflect the effects of land use change on aquatic organisms at large spatial and temporal scales. Almeida et al. [18] demonstrated that fish biotic integrity indices were positively correlated with forest cover and negatively correlated with agricultural and urban land cover percentages in a large Mediterranean river. Macroinvertebrates are also common in freshwater ecosystems and good indicators of changes in environmental conditions that are favored by many ecological researchers [19]. They are easily sampled and are a very biodiverse group that may inhabit waters contaminated to different extents from clean to highly polluted. Macroinvertebrates are also important for the cycling of organic matter and provide food resources for higher trophic levels. Wang et al. [20] showed that the diversity and community structure of macroinvertebrates exhibited obvious changes when forestland was converted to agricultural land because the proportion of Annelida taxa increased and the number of aquatic insects decreased. Diatoms are primary producers in the aquatic ecosystem and important food sources for higher trophic level organisms. Because diatoms are incapable of movement, they can be more sensitive to water quality changes that are caused by land use changes. Vázquez et al. [4] argued that diatom assemblages respond to micro-watershed conditions and can be used to monitor the effects of land use on streams in tropical regions. Moreover, their results indicated that forest coverage was positively correlated with acidophilus and oligo-eutraphentic diatom species, and coffee coverage was significantly positively correlated with motile species and significantly negatively correlated with pollution-sensitive diatom taxa. Li et al. [21] indicated that the biomass, abundance, richness, average density, and biological diatom index (IBD) of diatoms were higher in forestland than in any other land use. However, most of these studies used signal species to analyze the relationship between land use type and organism community. Different organisms will have different responses to the environment. Understanding the relationship between several organism communities and land use types will be beneficial for decision-making by governments or managers tasked with monitoring or restoring the aquatic ecosystem.

The Wei River basin is located in central China, where the development speed is limited and slower than that in the eastern part of China [22]. However, during the last decade, the local economy has grown very rapidly. Thus, developing methods of balancing social development and ecological security is becoming a crucial challenge for future development plans. Therefore, the objectives of this research were to (1) understand the distribution of land use types in the Wei River basin, (2) determine the relationship between the biological indices and land use types, and (3) determine which organism community would be a better indicator in routine monitoring. We hope that the results of this study will be valuable for urban planners and managers to make better decisions for future developments. 


\section{Materials and Methods}

\subsection{Study Area Description}

The Wei River is the largest tributary of the Yellow River and is located in central China. Its elevation ranges from 227 to $3936 \mathrm{~m}$ (Figure 1). The mainstream length is approximately $818 \mathrm{~km}$ with a drainage area of $1.34 \times 10^{5} \mathrm{~km}^{2}$. The Jing River is the largest tributary of the Wei River and flows across $455.1 \mathrm{~km}$ with a drainage area of $4.54 \times 10^{4} \mathrm{~km}^{2}$. The Beiluo River is the second largest tributary of the Wei River and flows across $680.3 \mathrm{~km}$ with a drainage area of $2.69 \times 10^{4} \mathrm{~km}^{2}$ [23].

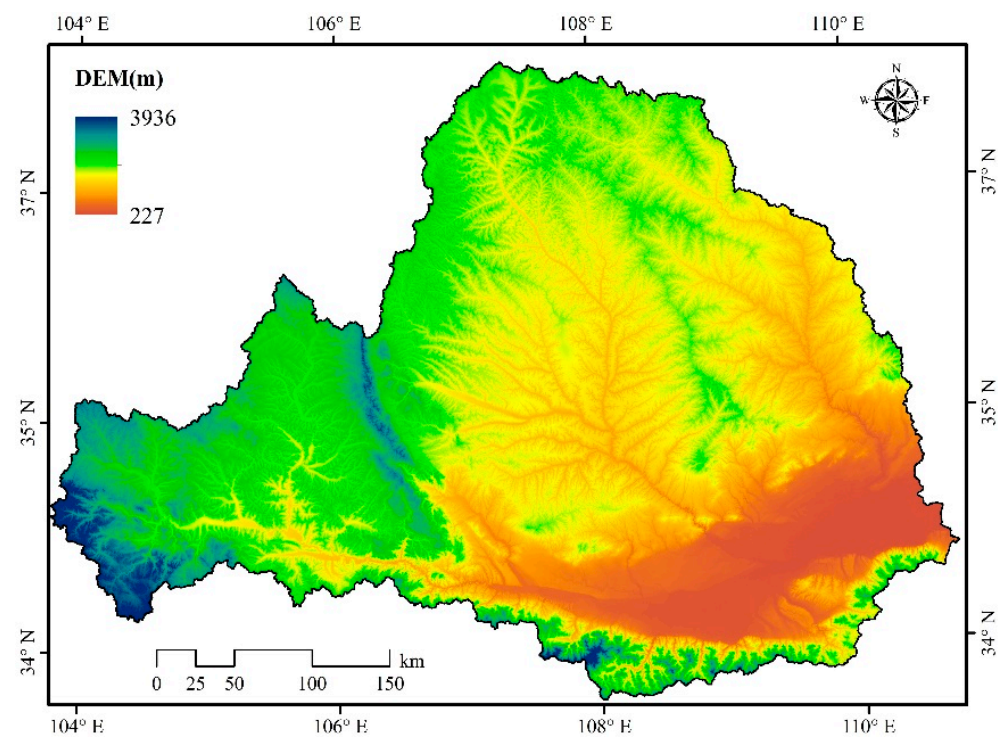

Figure 1. Elevation of the Wei River basin.

The geomorphology of the Wei River basin is complicated. The southern part of the basin is surrounded by the Qinling Mountains; however, the northern and western parts of the basin are on the Loess Plateau, where soil erosion is severe, which results in high turbidity and low transparency. The terrain comprises the Guanzhong Plain in the eastern part of the basin, where anthropogenic activities, such as high urbanization, industrialization, and commercialization, are common [24].

The Wei River basin is located in the arid to humid transition zone, and the climate is continental monsoon. The mean annual air temperature is approximately $3.7-13.9{ }^{\circ} \mathrm{C}$, and the mean annual precipitation is approximately $290-910 \mathrm{~mm}$. The wet season usually occurs from July to October when many rainstorms bring high amounts of precipitation. Runoff during the wet season accounts for $60 \%$ of the yearly total. The precipitation minimum usually occurs in January and December, when only $1.6-3.1 \%$ of the yearly runoff occurs [25].

\subsection{Data Collection}

\subsubsection{Sampling Sites}

Sixty sampling sites were selected to investigate the characteristics of the fish, macroinvertebrate and diatom communities in October 2012 (wet season) and April 2013 (dry season). These sampling sites covered the entire basin. Most of the sampling stations were located in the fourth- or fifth-order streams because these streams were strongly affected by various human activities [26]. The sampling sites were divided into three groups: (1) W sites, which included 32 sampling sites located in the Wei River catchment; (2) J sites, which included 15 sampling sites located in the Jing River catchment; and (3) BL sites, which included 13 sampling sites in the Beiluo River catchment (Figure 2). A total of 120 samples were collected during these two periods for each biotic assemblage. 


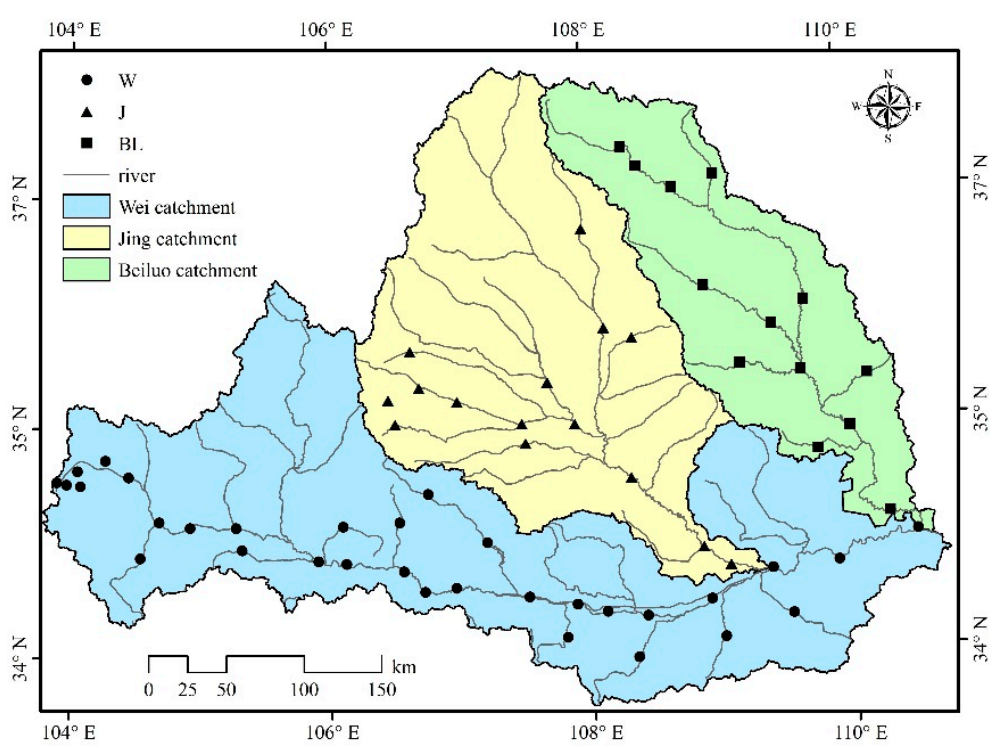

Figure 2. Sampling sites in the Wei River basin.

\subsubsection{Fish Sampling}

For the wadable streams, fish were collected across 200-300 $\mathrm{m}$ at each site using electrofishing for 30 min within. All types of habitat were included, such as pools, runs, and riffles. In the unwadable streams, fish collection was performed by boat using seines $(30 \times 40 \mathrm{~mm})$. We identified the fish in situ by referring to the relevant reference books Chen (1998). Each fish species was counted and weighed using an electronic scale.

\subsubsection{Macroinvertebrate Sampling}

Macroinvertebrates were collected using a Surber sampler $(30 \times 30 \mathrm{~cm})$. For each sampling site, two parallel samples were collected from different randomly selected habitats, including stones, marginal areas, sand, mud, leaves, and vegetation (6-12 Surber samples for each site). All samples were mixed on a white tray, and the macroinvertebrates were collected and placed into a plastic bottle containing a $95 \%$ alcohol solution for preservation. The samples were identified in the laboratory by an anatomical lens or a microscope depending on the reference [27-29]. Each taxon was identified to the family or genus level.

\subsubsection{Epilithic Diatom Sampling}

At each sampling station, three equal-sized pebbles were randomly selected and scraped by a toothbrush and bottle cap $\left(11.34 \mathrm{~cm}^{2}\right)$ to obtain the diatom samples from an equivalent size area. All samples were collected in a plastic bottle containing $4 \%$ formalin and transported to the laboratory, where they remained undisturbed for $48 \mathrm{~h}$. Then, the supernatant liquids were extracted, and the remnant liquids were concentrated at $100 \mathrm{~mL}$ for future analysis. The diatom samples were corroded by concentrated nitric acid and sulfuric acid. Two replicate slides were taken for each sampling site, and 1000 valves per slide were identified under a microscope with a magnification of $1000 \times$ as described by Hu and Wei [30] and Zhu and Chen [31]. Each taxon was identified to the species level.

\subsubsection{Biodiversity Indices}

Six biological indicators, i.e., richness, abundance, Shannon diversity (SD), Shannon evenness (SE), Margalef diversity (MD), and Simpson diversity (SP) were calculated for each community. Richness 
was calculated based on the taxonomic classification. Diversity and evenness were calculated as follows:

$$
\begin{gathered}
S D=-\sum_{i=1}^{S} p_{i} \log _{2} p_{i} \\
S E=\frac{S D}{\log _{2} S} \\
S P=1-\sum_{i=1}^{S} p_{i}^{2} \\
M D=\frac{(S-1)}{\ln N}
\end{gathered}
$$

where $p_{i}$ is the proportion of individuals found in the $i$ th taxon; $S$ is the total number of organisms in the sample; and $N$ is the total number of individuals in the sample.

\subsubsection{Physiochemical Variable}

Dissolved oxygen (DO) and electrical conductivity (EC) were measured in situ using a YSI Pro plus 85. Two-liter water samples were collected from each sampling station and sent to the laboratory within $48 \mathrm{~h}$. Total nitrogen (TN), total phosphorus (TP) and chemical oxygen demand (COD) were measured in the laboratory following the standards from the State Environmental Protection Administration of China (GB 3838-2002). The Qualitative Habitat Evaluation Index (QH) was used to evaluate the condition of the habitat according to Barbour et al. [32].

\subsubsection{Land Use Type}

The land use types of the Wei River basin were obtained from the National Geomatics Center of China. The land use types were divided into the following eight categories according to the $30-\mathrm{m}$ global land cover dataset from 2010 (Figure 3): agricultural land, forestland, grassland, shrubland, wetland, aquatic land, urban land, and bare land. Because forestland, grassland, agricultural land and urban land accounted for more than $99 \%$ of the Wei River basin, these four land use types were considered in the subsequent analysis.

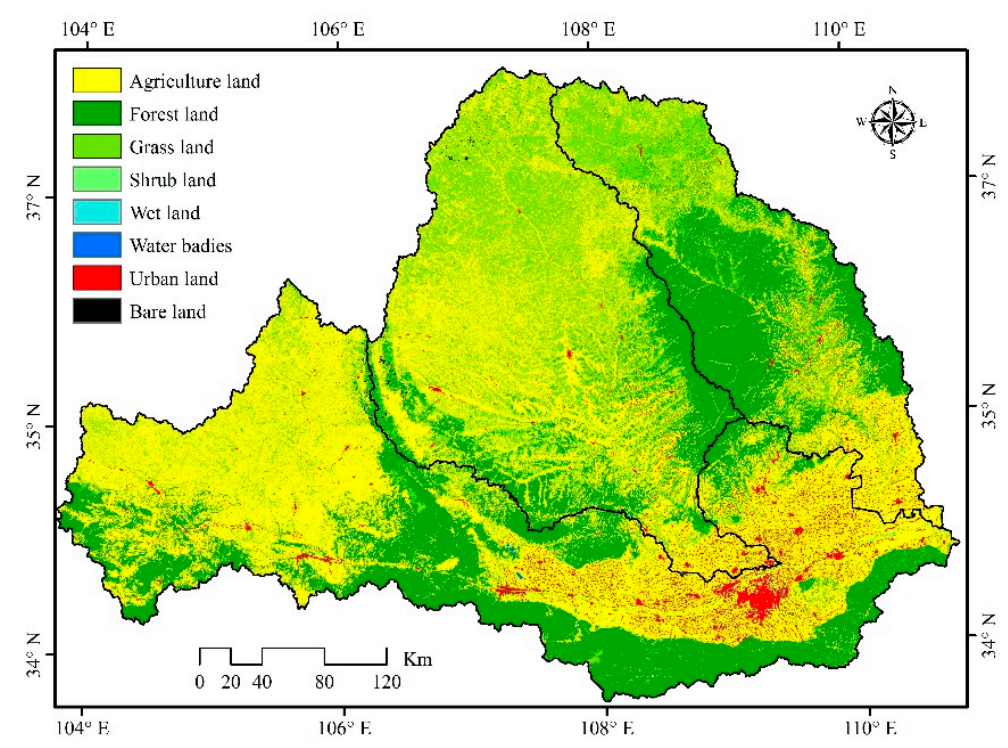

Figure 3. Land use types of the Wei River basin. 
Each sampling site was selected as an outlet point, and the Wei River basin was delineated into 60 subbasins depending on the digital elevation model (DEM) at a $30 \times 30-\mathrm{m}$ resolution. Then, we obtained the land use composition of each sampling site at the sub-basin level.

\subsection{Data Analysis}

The averages of each biological index, physiochemical variable, and land use type were calculated in the Wei River catchment, Jing River catchment and Beiluo River catchment, and the range was displayed by boxplots and violin figures to express the discrimination of the three catchments. The Indicator Species Analysis was used to define the indicator species for each catchment using PC-ORD 5.0 soft (https://www.pcord.com/pc5fixes.htm) [22].

The Kolmogorov-Smirnov test (K-S test) was used to examine whether all variables fit a normal distribution. In this study, values of $p>0.05$ indicated that the variables fit a normal distribution. For such variables, Pearson's correlation analysis was used to analyze the relationships between the biological indices and land use types and physiochemical variables.

Before analyzing the correlations between biotic abundance and environmental variables, a detrended correspondence analysis (DCA) was conducted to determine the model (linear model or unimodal model) that would be more appropriate for further analysis [22]. In this study, the gradient lengths of macroinvertebrate and fish abundance were greater than 3; therefore, a canonical correspondence analysis (CCA-unimodal model) was used to analyze the effects of land use type and physiochemical variables on the macroinvertebrate and fish communities. However, for gradient lengths of diatom abundance lower than 3, a redundancy analysis (RDA) was more appropriate for analyzing the association of diatom assemblages with environmental variables.

\section{Results}

\subsection{Land Use Characteristics}

The 30-m global land cover dataset in 2010 showed that agricultural land (AL) was the main land use type in the basin and accounted for $48.4 \%$ of the total area (Figure 4 ). At the reach scale, the proportion of AL was lowest in the BL catchment at nearly $43.3 \%$, and it was $58.8 \%$ and $65.2 \%$ in the $\mathrm{W}$ and J catchments, respectively (Figure 5). The next most abundant land use types were forestland (FL) and grassland (GL), which were mainly distributed in the southern and northeastern parts of the Wei River basin, and they accounted for $28.9 \%$ and $19.0 \%$ of the total area, respectively (Figure 4). The proportion of FL and GL were both highest in the BL catchment at $10.7 \%$ and $42.9 \%$, respectively, at the reach scale. The proportion of FL in the W catchment $(9.5 \%)$ was higher than that in the J catchment $(1.7 \%)$, whereas the results for GL showed an opposite trend, with proportions of $30.3 \%$ and $26.7 \%$ in the $\mathrm{J}$ and $\mathrm{W}$ catchments, respectively (Figure 5). Although the urban land area (UL) was relatively small, it was concentrated in the Guanzhong Plain in the eastern part of the basin, and the urban land area accounted for 3.0\% of the total area (Figure 4). Most of the urban land area was distributed in the $\mathrm{W}$ catchment, and the proportion was $1.8 \%$, which was twice the value in the J catchment. Urban land in the BL catchment was rather small at a proportion of only $0.2 \%$ (Figure 5). 


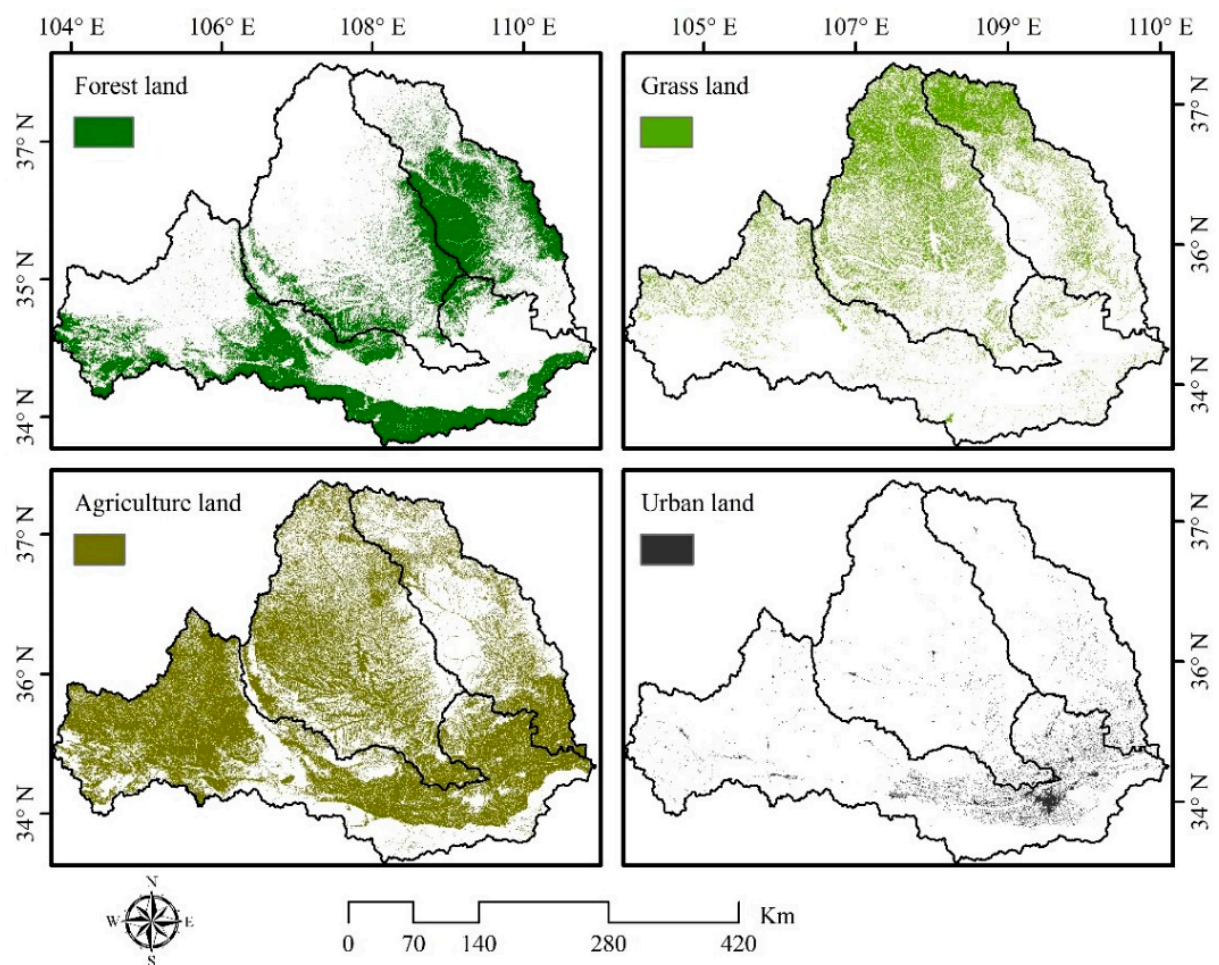

Figure 4. Distribution of the four land use types in the Wei River basin.

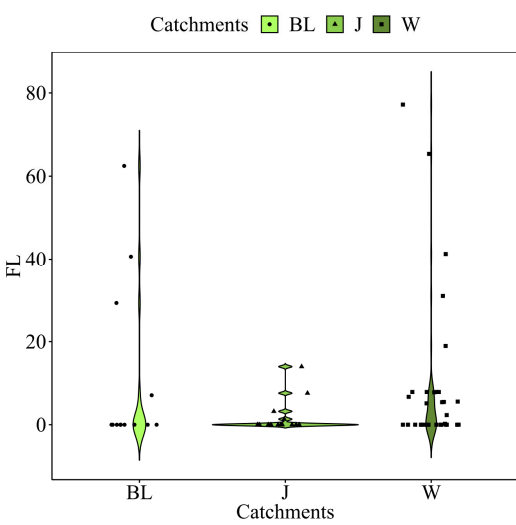

(a)

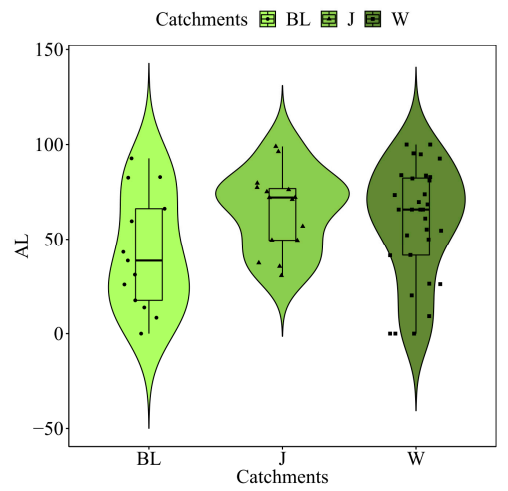

(c)

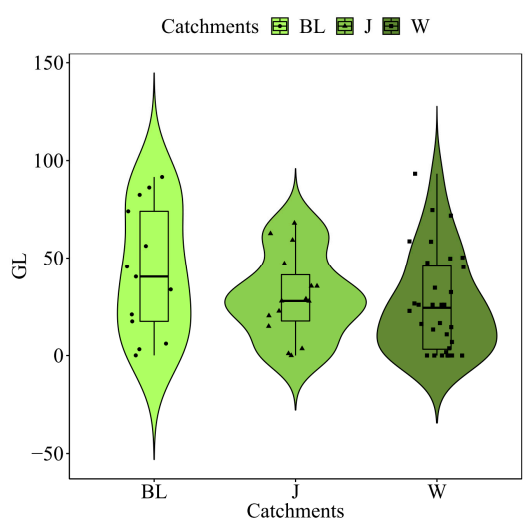

(b)

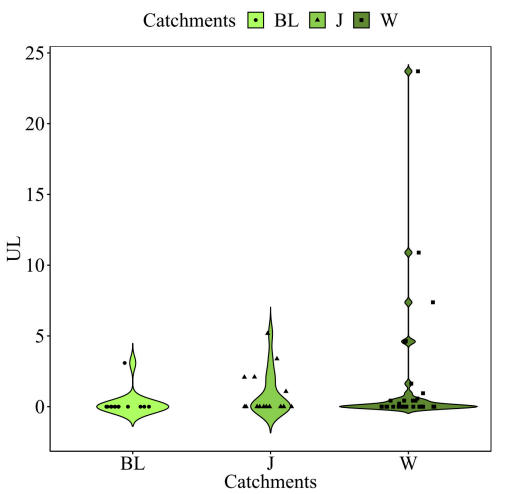

(d)

Figure 5. Distribution of the four land use types at three catchments in the Wei River basin. (a): forestland (FL), (b): grassland (GL), (c): agricultural land (AL), (d): urban land (UL). 


\subsection{Physiochemical variables}

Significant differences were observed for some variables in some catchments. QH, DO, and EC were slightly higher in the BL catchment than in the other catchments, and the average values were $125.7,11.0 \mathrm{mg} / \mathrm{L}$, and $1311.5 \mathrm{us} / \mathrm{cm}$ therein and $121.5,9.4 \mathrm{mg} / \mathrm{L}$, and $392.0 \mathrm{us} / \mathrm{cm}$ in the $W$ catchment and $116.9,10.6 \mathrm{mg} / \mathrm{L}$, and $1006.6 \mathrm{us} / \mathrm{cm}$ in the J catchment, respectively. TN, TP, and COD were a slightly higher in the $W$ catchment than in the other catchments, with average values of $13.9 \mathrm{mg} / \mathrm{L}, 0.6 \mathrm{mg} / \mathrm{L}$, and $4.96 \mathrm{mg} / \mathrm{L}$ therein, and $12.3 \mathrm{mg} / \mathrm{L}, 0.36 \mathrm{mg} / \mathrm{L}$, and $4.32 \mathrm{mg} / \mathrm{L}$ in the BL catchment, respectively. $\mathrm{TN}$ and COD were relatively lower in the J catchment than in the BL catchment, and the average values were $11.32 \mathrm{mg} / \mathrm{L}$ and $3.6 \mathrm{mg} / \mathrm{L}$, respectively. TP was higher in the J catchment and had an average value of $0.49 \mathrm{mg} / \mathrm{L}$ (Figure 6).
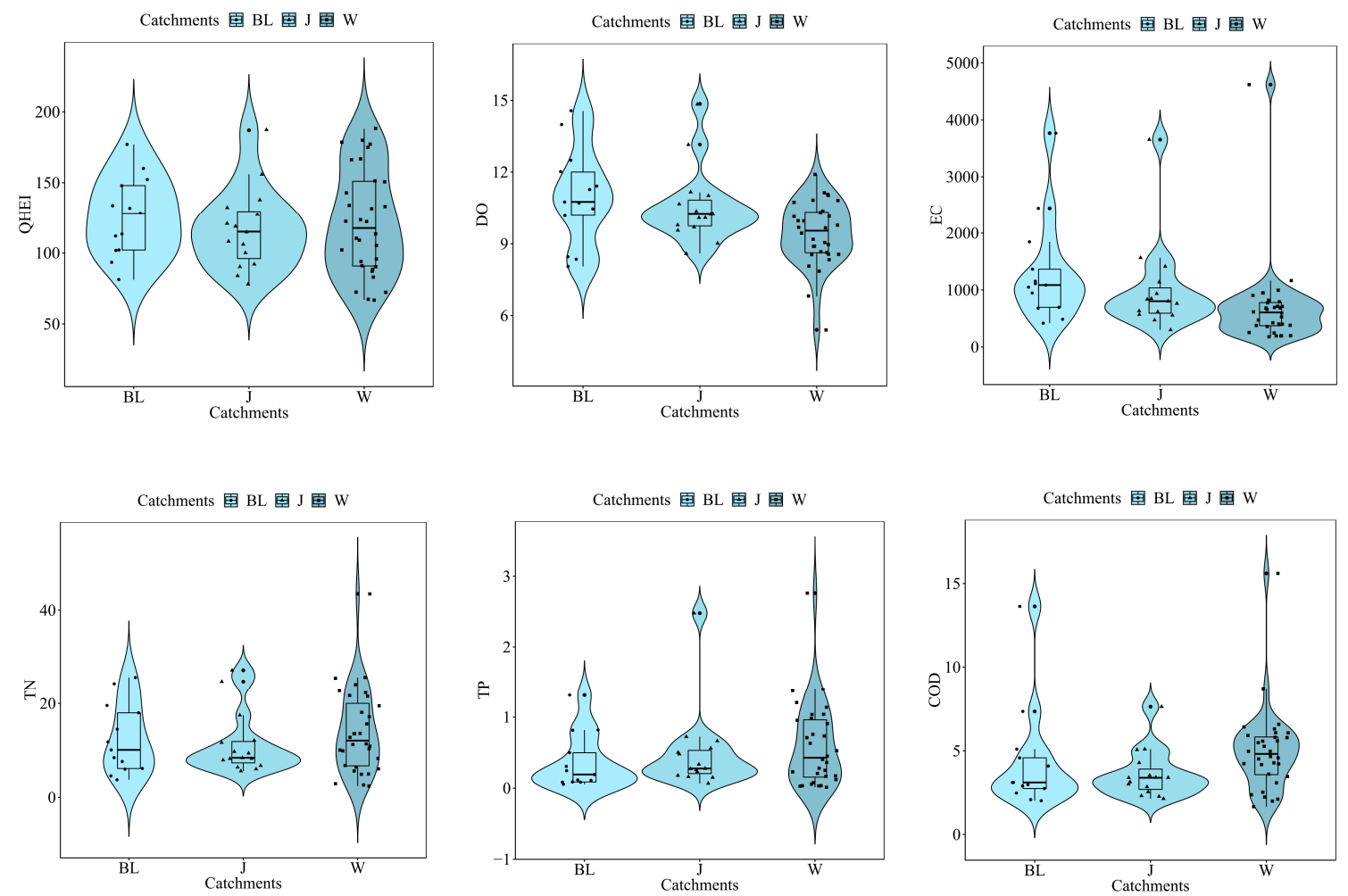

Figure 6. Distribution of physiochemical variables (QHEI, DO, EC, TN, TP, COD) at each catchment in the Wei River basin.

\subsection{Community Structure and Biological Indices}

A total of 251 diatom species belonging to 31 genera were collected. Navicula was the most numerous genus and included 61 species. The species Encyonema ventricosum and Achnanthidium minutissimum were the indicator species for the $\mathrm{W}$ catchment, and Pantocsekiella ocellata was the indicator species for the J catchment. The number of indicator species of diatoms for the BL catchment was much higher than that of the above catchments, and the indicator species included Diatoma elongata, Achnanthidium minutissimum var. cryptocephala, Chamaepinnularia begeri, Caloneis budensis, and Neidium kozlowi var. elliptica (Table 1). In total, 73 macroinvertebrate species were identified, and they represented seven classes and 12 orders. Diptera was the dominant order and included 34 species in the Wei River basin. Orthocladius makabensis, Rheocricotopus fuscipes, Polypylis hemisphaerula, Limnodrilus claparedianus, and Sinopotamidae were the indicator species in the BL catchment; however, no macroinvertebrate indicator species were observed in the $\mathrm{W}$ and $\mathrm{J}$ catchments (Table 1). A total of 45 fish species were recorded in this study, and the most indicator fish species were observed in the W catchment, including Triplophysa minxianensis, Cobitis granoei, Huigobio chinssuensis, and Gobio 
coriparoides. Only one indicator fish species was found in the J catchment (Triplophysa kungessana orientalis) and BL catchment (Gnathopogon imberbis).

Table 1. Indicator species at each catchment in the Wei River basin. See Appendices A-C for abbreviations of the diatom, macroinvertebrate and fish species.

\begin{tabular}{ccccc}
\hline Catchments & ID & Species & Value & P \\
\hline \multirow{5}{*}{ W Catchment } & D126 & Encyonema ventricosum & 41.4 & 0.003 \\
& D182 & Achnanthidium minutissimum & 41.1 & 0.004 \\
& F6 & Triplophysa minxianensis & 37.9 & 0.008 \\
& F14 & Cobitis granoei & 28.1 & 0.016 \\
& F27 & Huigobio chinssuensis & 25.0 & 0.019 \\
& F33 & Gobio coriparoides & 24.3 & 0.042 \\
\hline \multirow{3}{*}{ Catchment } & D225 & Pantocsekiella ocellata & 41.0 & 0.002 \\
& F10 & Triplophysa kungessana orientalis & 37.3 & 0.004 \\
\hline & D159 & Diatoma elongata & 53.8 & 0.001 \\
& D183 & Achnanthidium minutissimum var. cryptocephala & 43.6 & 0.001 \\
& D14 & Chamaepinnularia begeri & 42.6 & 0.003 \\
& D65 & Caloneis budensis & 29.2 & 0.005 \\
& D236 & Neidium kozlowi var. elliptica & 30.8 & 0.002 \\
& B25 & Orthocladius makabensis Sasa & 42.8 & 0.001 \\
& B33 & Rheocricotopus fuscipes & 27.5 & 0.005 \\
& B61 & Polypylis hemisphaerula & 17.7 & 0.038 \\
& B66 & Limnodrilus.claparedianus & 31.3 & 0.012 \\
& B71 & Sinopotamidae & 13.3 & 0.042 \\
& F26 & Gnathopogon imberbis & 30.9 & 0.035 \\
\hline
\end{tabular}

For the BL catchment, the richness of diatoms and macroinvertebrate was the highest among the three catchments, and the average values were nearly 45.4 and 5.9, respectively. The richness of fish in the BL catchment was lower than that of the $\mathrm{W}$ catchment but higher than that of the J catchment, reaching a mean value of 8.2. For the J catchment, the richness of fish and macroinvertebrates was the lowest among the three catchments, and the average values were 6.9 and 4.7 , respectively. The mean richness value of diatoms was 40.5 . For the $\mathrm{W}$ catchment, the richness of fish was the highest among the three catchments, with a mean value of 10.6. The average richness of diatom and macroinvertebrates was 5.5 and 40.3, respectively (Figure 7).
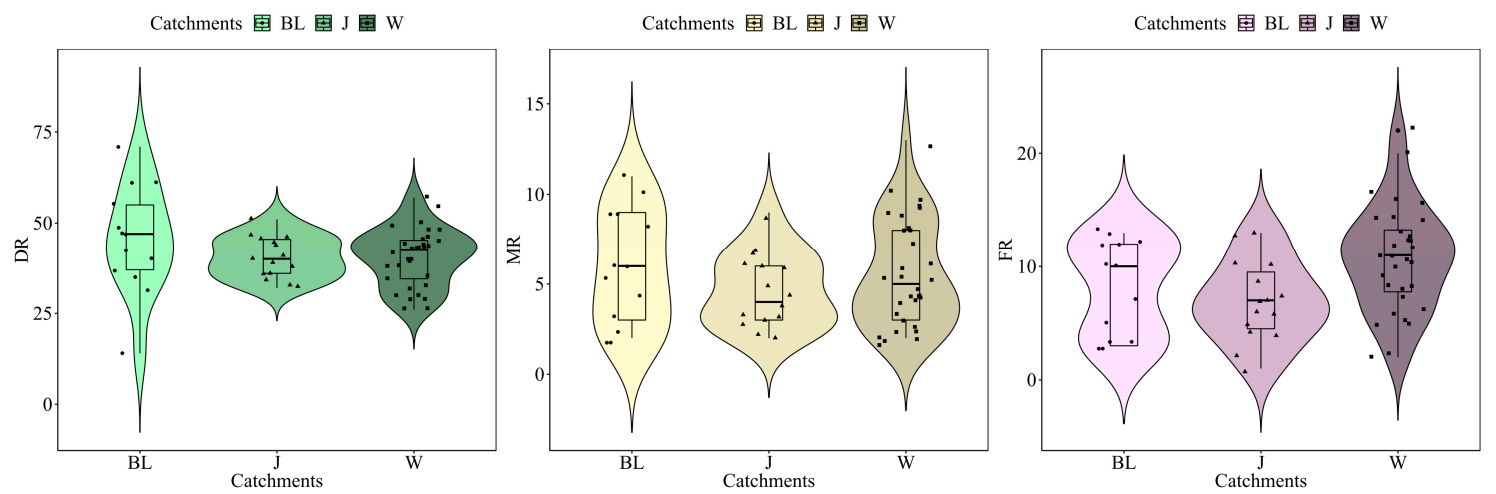

Figure 7. Distribution of three biotic indicators of diatom, macroinvertebrate and fish assemblages at each catchment in the Wei River basin. DR: diatom richness, MR: macroinvertebrate richness, FR: fish richness.

\subsection{Correlations between Biological Indices and Environmental Variables}

For the diatom indices, only richness, abundance, and Simpson diversity were significantly associated with $\mathrm{COD}, \mathrm{QH}$, and DO, respectively. For the macroinvertebrate biotic indices, $\mathrm{QH}$ and TP 
both had a great effect on the four biological indices. Macroinvertebrate richness and Margalef diversity were both statistically correlated with QH and TP, while macroinvertebrate abundance was associated with $\mathrm{QH}$ and macroinvertebrate Simpson diversity was associated with TP. Macroinvertebrate richness and macroinvertebrate Margalef diversity were also affected by EC. In addition, macroinvertebrate Margalef diversity was associated with COD as well. For the fish, all of the biotic indices had a significant correlation with EC except evenness. GL had a strong association with fish richness, Shannon diversity, Margalef diversity and Simpson diversity. FL was correlated with fish richness and Shannon diversity, while UL was associated with fish richness and Margalef diversity. Only DO had a strong correlation with fish evenness (Figure 8).

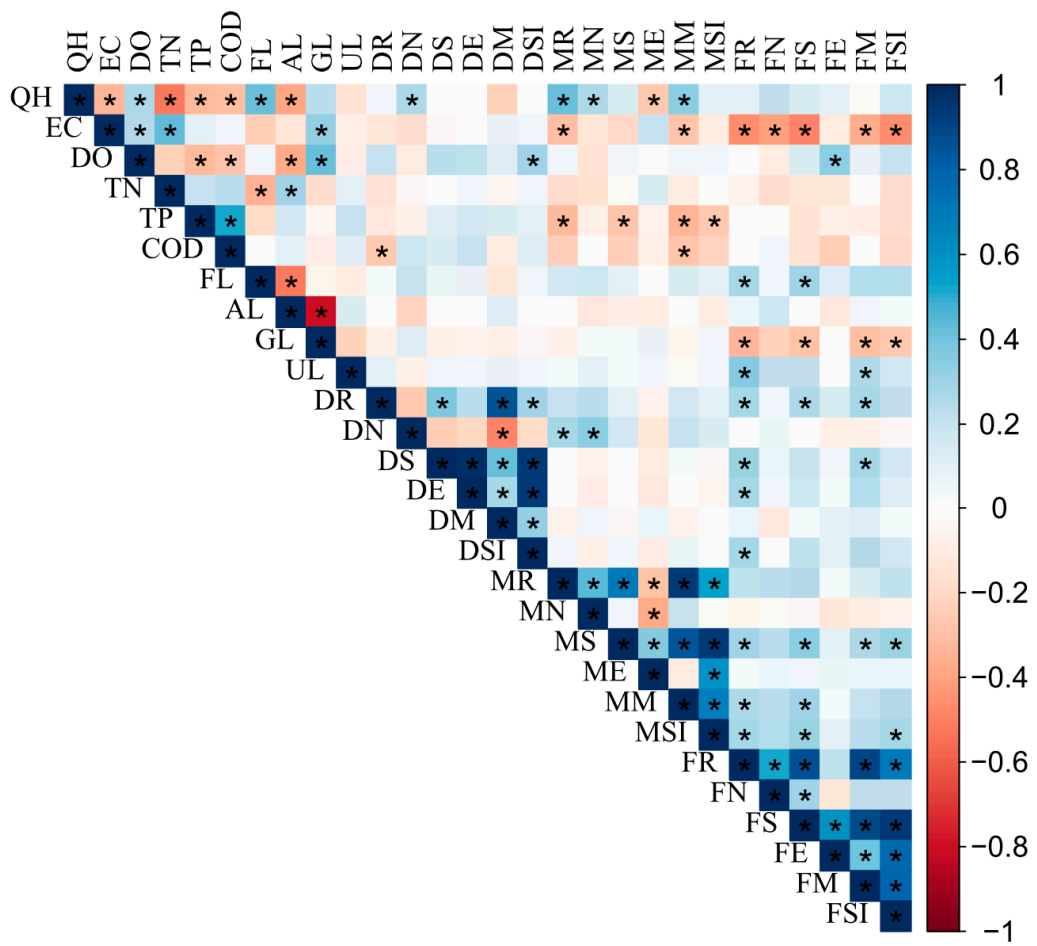

Figure 8. Correlation matrix between environmental variables and biotic indicators in the Wei River basin (* $p$ 0.05). D: diatom, M: macroinvertebrate, F: fish, R: richness, N: abundance, S: Shannon diversity, E: evenness, M: Margalef diversity, and SI: Simpson diversity.

\subsection{Relationships between Biological Assemblages and Environmental Variables}

In the RDA model for the diatom assemblage, axes 1 and 2 explained $5.4 \%$ and 3.3\% of the variation, respectively (Table 2). The Monte Carlo permutation test indicated that QH, FL, and GL had a significant influence on diatom assemblages $(p<0.05)$ (Table 3). Encyonema ventricosum and Achnanthidium minutissimum, which were the indicator species, were positively correlated with $\mathrm{QH}$ and FL (Figure 9). Pantocsekiella ocellata was the indicator species for the J catchment, and it was positively associated with COD. Diatoma elongata and Caloneis budensis had great positive association with COD, and Achnanthidium minutissimum var. cryptocephala and Chamaepinnularia begeri were strongly correlated with GL and FL, respectively. In the CCA for the macroinvertebrates, TN and AL were selected as the main factors influencing assemblage structure. Axes 1 and 2 explained 20.1\% and 18.3\% of the variation, respectively. Limnodrilus claparedianus was associated with TN, and Sinopotamidae was correlated with AL. In the CCA model for fish, QH, DO, TP and GL had significant associations with the assemblage structure. Axes 1 and 2 explained $29.8 \%$ and $14.6 \%$ of the variation, respectively. Huigobio chinssuensis, Gobio coriparoides, and Triplophysa kungessana orientalis were strongly associated with TP; meanwhile, Cobitis granoei and Gnathopogon imberbis were not. Triplophysa minxianensis had a high correlation with QH and DO. 
Table 2. Eigenvalues and species-environment correlations of each canonical axis.

\begin{tabular}{ccccccc}
\hline \multirow{2}{*}{ Axis } & \multicolumn{2}{c}{ Diatom } & \multicolumn{2}{c}{ Macroinvertebrate } & \multicolumn{2}{c}{ Fish } \\
\cline { 2 - 7 } & Eigenvalues & Correlations & Eigenvalues & Correlations & Eigenvalues & Correlations \\
\hline Axis 1 & 0.054 & 0.816 & 0.201 & 0.751 & 0.298 & 0.763 \\
Axis 2 & 0.033 & 0.786 & 0.183 & 0.748 & 0.146 & 0.698 \\
Axis 3 & 0.026 & 0.753 & 0.124 & 0.757 & 0.092 & 0.660 \\
Axis 4 & 0.022 & 0.842 & 0.105 & 0.724 & 0.061 & 0.674 \\
\hline
\end{tabular}

Table 3. Results of the Monte Carlo permutation tests in redundancy analysis (RDA) and canonical correspondence analysis (CCA).

\begin{tabular}{ccccccc}
\hline \multirow{2}{*}{ Variable } & \multicolumn{2}{c}{ Diatom } & \multicolumn{2}{c}{ Macroinvertebrate } & \multicolumn{2}{c}{ Fish } \\
\cline { 2 - 7 } & $\mathbf{F}$ & $\mathbf{P}$ & $\mathbf{F}$ & $\mathbf{P}$ & $\mathbf{F}$ & $\mathbf{P}$ \\
\hline QH & 2.88 & $\mathbf{0 . 0 0 1}$ & 1.15 & 0.251 & 3.84 & $\mathbf{0 . 0 0 1}$ \\
DO & 0.99 & 0.438 & 1.34 & 0.091 & 2.14 & $\mathbf{0 . 0 0 6}$ \\
EC & 0.93 & 0.596 & 0.91 & 0.596 & 1.03 & 0.405 \\
TN & 1.04 & 0.416 & 1.85 & $\mathbf{0 . 0 0 7}$ & 1.20 & 0.261 \\
TP & 0.67 & 0.886 & 1.05 & 0.401 & 2.05 & $\mathbf{0 . 0 2 8}$ \\
COD & 1.23 & 0.168 & 0.93 & 0.550 & 0.62 & 0.870 \\
FL & 1.51 & $\mathbf{0 . 0 2 4}$ & 1.08 & 0.366 & 1.17 & 0.240 \\
GL & 1.38 & $\mathbf{0 . 0 3 9}$ & 0.75 & 0.807 & 1.63 & $\mathbf{0 . 0 3 2}$ \\
AL & 1.20 & 0.172 & 1.51 & $\mathbf{0 . 0 4 4}$ & 1.10 & 0.326 \\
UL & 0.88 & 0.593 & 1.02 & 0.393 & 0.79 & 0.660
\end{tabular}

The bold numbers indicate that the variables had a significant influence on the biological assemblages.

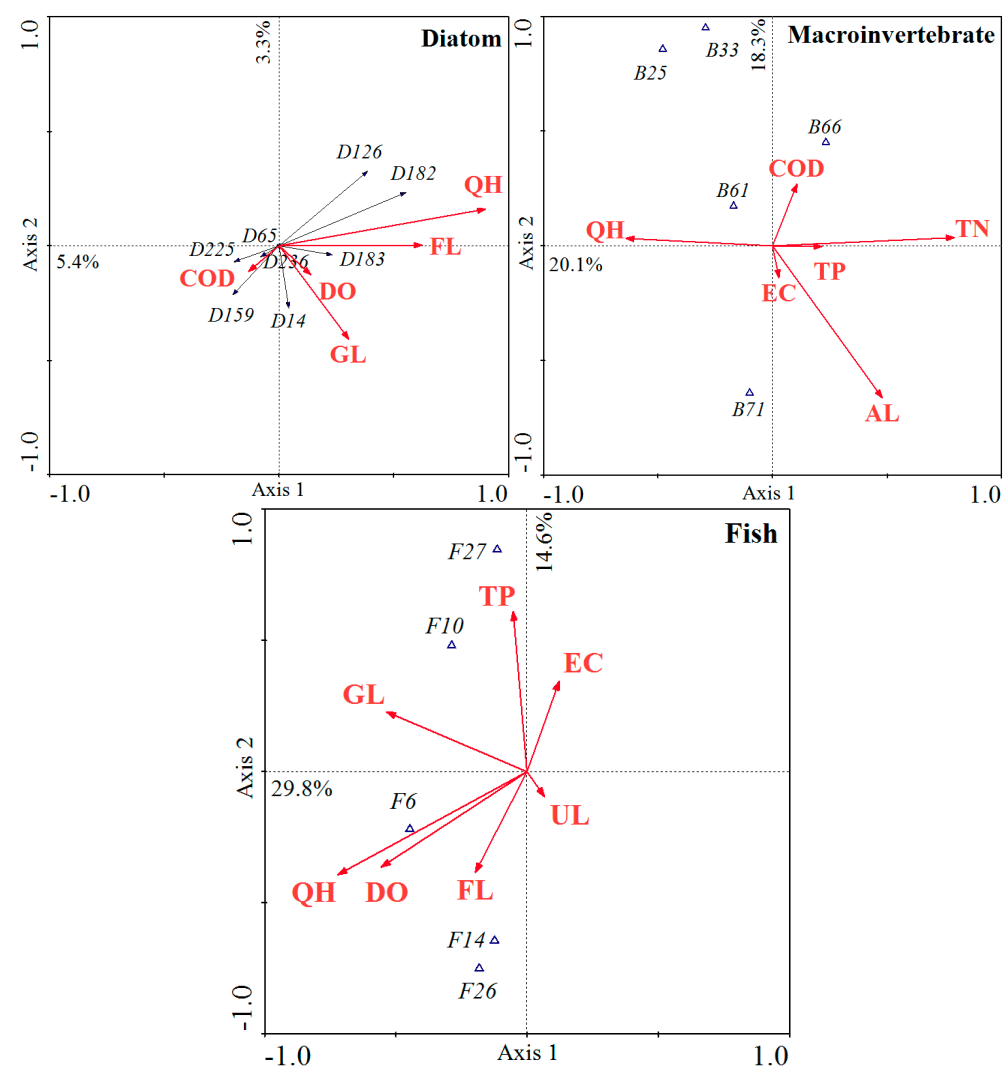

Figure 9. Redundancy analysis (RDA) between diatom metrics and environmental variables and canonical correspondence analysis (CCA) of macroinvertebrate and fish metrics and environmental variables in the Wei River basin. See Appendices A-C for abbreviations of the diatom, macroinvertebrate and fish species. 


\section{Discussion}

\subsection{Characteristic of Aquatic Ecosystems}

Anthropogenic influences and land use are most likely responsible for the variations in water quality [33]. In our study, $\mathrm{QH}$ and DO were the highest in the BL catchment and TN and TP were the lowest. Meanwhile, the percentage of agricultural land and urban land were obviously lower in the BL catchment than in the other catchments while the percentages of forestland and grassland were higher. Moreover, the richness of diatoms and macroinvertebrates was the highest in the BL catchment. These findings suggest that land use may affect the water quality and biological community structure, which is consistent with a number of previous studies [18,34,35]. Ding [12] found that water quality was most strongly affected by the configuration metrics of land use. Agricultural land was the main land use type in the Wei River basin at both the large scale and the reach scale, suggesting that aquatic ecosystems were severely affected by the agricultural activity. Urban land, which accounted for 3\% of the area, was a minor land use type in the Wei River basin, indicating that economic development was relatively slower than that observed in the eastern parts of China, such as in Shanghai or Hangzhou. Therefore, non-point pollution was considered the main source of contamination in the Wei River basin because of the higher proportion of agricultural land and lower proportion of urban land [23]. Other studies, such as Longyang [36], reported that runoff would carry agrochemicals into rivers and cause non-point source pollution. Forest land and grassland are often considered filter strips that could decrease the nutrient content of water resources caused by non-point pollution, reinforce bank stability and provide aquatic habitats [26].

\subsection{Influence of Environmental Variables on Biological Indices}

The indices of macroinvertebrates and fish were more sensitive to the environmental parameters than the indices of diatoms in Wei River basin, and the macroinvertebrate indices were more strongly correlated with physicochemical variables while the fish indices were more strongly correlated with the land use type. The weak correlations observed for the indices based on diatom were primarily related to the degraded habitat and high amounts of silt sediment. The Loess Plateau is located in the Wei River basin, and considerable amounts of runoff with silt or sand enter the river and lead to finer sediment, which decreases the survival of diatoms. Many studies have indicated that diatom indices are sensitive to the nitrogen or phosphorous content and are beneficial indicators for evaluating the eutrophication conditions of freshwater ecosystems [37-40]. In our study, diatom richness was correlated with organic pollution, such as COD, indicating that the nutrient content was not sufficient to cause eutrophication; rather, organic pollution was the major limiting factor for diatom growth. Although many studies have demonstrated that diatom assemblages represent the "first choice" for detecting nutrient enrichment levels in water quality [26,37,39], several studies have confirmed that diatom indices could be a useful indicator for predicting organic pollution as well [41]. Hence, diatom indices could be used as an indicator for organic pollution in the Wei River basin. All of the macroinvertebrate indices had a strong correlation with environmental variables, especially the macroinvertebrate richness and Margalef diversity. QH and TP were the major environmental parameters that influenced the four macroinvertebrate indices. Zhang et al. [42] demonstrated that the concentration of nitrogen had a great effect on the distribution of the macroinvertebrate community in basins where agricultural area was the main land use type, which is consistent with our results. The fish indices were also strongly associated with environmental variables in our study, especially EC. Maceda-Veiga et al. [43] showed that high water conductivity was negatively correlated with migratory, pelagic, invertivorous and native fish in Spain and suggested that the current condition of riparian zones was sufficient to decrease the pollution effects on fish, with high conductivity presenting a significant inverse association with the length of the food chain [44]. In conclusion, diatom and macroinvertebrate indices represent better indicators for organic pollution and eutrophication, respectively, and fish indices represent better indicators for conductivity in the Wei River basin. 


\subsection{Response of Biological Assemblages to Environmental Variables}

The results of the RDA showed that QH, FL, and GL were significantly correlated with the diatom assemblages. Forest land and grassland were strongly correlated with the water quality and indirectly affected the biological assemblages [26]. We found that Encyonema and Achnanthidium preferred habitat with a higher percentage of forest or grassland use, consistent with several studies indicating that these genera are indicators of good water quality. For instance, some studies showed that Achnathidium minutissimum was so sensitive to water quality that it was rarely observed in impaired sites, especially when the phosphorus content was over $0.3 \mathrm{mg} / \mathrm{L}[37,45]$. Pantocsekiella has been defined as a tolerant species that can indicate polluted areas. Shen et al. [39] divided the Ying River into three regions based on nutrient status and found that Achnathidium minutissimum was the dominant species in the region with the lowest nutrient level, whereas Pantocsekiella meneghiniana was the dominant species in the region with the highest nutrient level. These findings are consistent with our results. TN and AL were the significant variables for the macroinvertebrate assemblage in the Wei River basin. The richness and diversity indices and assemblage structure were correlated with nutrient variables, suggesting that the macroinvertebrates could be indicators of nutrition status in the Wei River basin. Limnodrilus was extensively adaptable to the environment and often acted as the dominant species in impaired stations. Because of the extreme tolerance of this species, it generally indicated poor water quality [46-49]. In this study, Limnodrilus was strongly positively associated with TP, TN and COD, consistent with previous studies $[48,49]$. In addition, QH, TP, DO and GL were all significantly correlated with the fish assemblages in the Wei River basin. Wu et al. [50] demonstrated that Triplophysa was the dominant species at altitudes over $800 \mathrm{~m}$, corresponding to locations at the origin of the river in the Wei River basin, which generally present good water quality. Our results showed that Triplophysa minxianensis was associated with QH and DO, which was in agreement with the results of Wu et al. [50]. Moreover, the fish indices and assemblage structure were strongly correlated with physiochemical variables and land use types, suggesting that fish could be considered the "best" organism for indicating the degree of pollution in the Wei River basin. Uncertainty was inevitable in the sampling process. We investigated only twice at different hydrological periods. The physiochemical parameters were easily affected by discharge and anthropogenic activities as well as biological assemblages, and this likely affects the relationships between biological indices and environmental variables. More investigation events would be required for future research.

\section{Conclusions}

This study demonstrated the response of fish, macroinvertebrate, and diatom assemblages to four land use types and six physiochemical variables in the Wei River basin. According to our results, diatoms were weakly associated with nutrient variables compared with macroinvertebrates and fish; however, macroinvertebrate indices and assemblages were significantly correlated with TP, TN, and AL, suggesting that they represented powerful indicators of the nutrient level in the Wei River basin. The fish indices and assemblage structure were strongly correlated with all variables but AL, TN, and COD, indicating that fish could adequately reflect spatial changes, such as the changes in land use type, in the Wei River basin. In conclusion, diatoms are not a good indicator in routine monitoring programs in the Wei River basin, macroinvertebrates could be beneficial for indicating the nutrient level, and fish represent the best indicator of spatial changes in the Wei River basin.

Author Contributions: Individual contributions of authors was as follows: Conceptualization, Z.X. and L.L.; methodology, L.L.; writing-original draft preparation, L.L.; writing-review and editing, Z.X.; investigation, X.Y. and W.W.; funding acquisition, Z.Z., F.Y. and J.L. All authors have read and agreed to the published version of the manuscript.

Funding: This study was supported by the National Natural Science Foundation of China (51279005) and Project for Science and Technology Innovation Guidance Fund of Hebei Provincial Department of Science and Technology.

Acknowledgments: The authors would like to thank Xuwang Yin for organizing the sampling survey and his colleagues for collecting and identifying the aquatic organisms. 
Conflicts of Interest: The authors declare no conflict of interest.

Appendix A. The Distribution of Diatom Assemblage in the W, J, and BL Catchments

Table A1. The list of diatom species in Wei River basin.

\begin{tabular}{|c|c|c|c|c|}
\hline ID & Species & $\mathbf{W}$ & $\mathbf{J}$ & BL \\
\hline D1 & Melosira varians & + & & + \\
\hline $\mathrm{D} 2$ & Melosira granulata & + & + & + \\
\hline D3 & Melosira granulata var. angustissima & + & & \\
\hline D4 & Navicula lanceolata & + & + & + \\
\hline D5 & Navicula exigua Krasske & & + & + \\
\hline D6 & Navicula confervacea & + & & + \\
\hline D7 & Navicula cryptocephala & + & + & + \\
\hline D8 & Navicula cryptocephala var. intermedia & + & + & + \\
\hline D9 & Navicula cryptocephala var. venta & + & + & + \\
\hline D10 & Navicula cincta & + & + & + \\
\hline D11 & Navicula cincta var. leptocephala & + & + & + \\
\hline D12 & Navicula cincta var. heufleri & & & + \\
\hline D13 & Navicula pusilla & + & & + \\
\hline D14 & Chamaepinnularia begeri & + & + & + \\
\hline D15 & Navicula pupula & + & + & + \\
\hline D16 & Navicula pupula var. capitata & + & + & + \\
\hline D17 & Navicula cuspidata & + & & \\
\hline D18 & Navicula cuspidata var. heribaudii & + & + & + \\
\hline D19 & Navicula radiosq & + & + & + \\
\hline $\mathrm{D} 20$ & Navicula cari & + & + & + \\
\hline $\mathrm{D} 21$ & Navicula cari var. angusta & + & & \\
\hline D22 & Navicula salinarum & & & + \\
\hline $\mathrm{D} 23$ & Navicula viridula & + & + & + \\
\hline $\mathrm{D} 24$ & Navicula viridula var. capitata & + & + & + \\
\hline $\mathrm{D} 25$ & Navicula viridula var. pamirensis & + & + & \\
\hline D26 & Navicula simplex & + & + & + \\
\hline $\mathrm{D} 27$ & Navicula gothlandica & + & + & + \\
\hline $\mathrm{D} 28$ & Navicula accommoda & + & + & + \\
\hline $\mathrm{D} 29$ & Navicula rhynchocephala & + & & + \\
\hline D30 & Navicula virihensis & + & + & + \\
\hline D31 & Navicula menisculus & + & + & + \\
\hline D32 & Naviclua anglica & + & & \\
\hline D33 & Navicula exigua Ehr & + & & \\
\hline D34 & Navicula gracilis & + & + & + \\
\hline D35 & Navicula gracilis var. neglecta & + & & + \\
\hline D36 & Navicula rostellata & & + & + \\
\hline D37 & Navicula seminulum & & + & \\
\hline D38 & Navicula seminuloides & + & + & + \\
\hline D39 & Navicula & + & + & + \\
\hline $\mathrm{D} 40$ & Navicula muralis & + & + & + \\
\hline $\mathrm{D} 41$ & Navicula notha & + & + & + \\
\hline $\mathrm{D} 42$ & Navicula halophilioides & + & + & + \\
\hline D43 & Navicula scabellum & & + & \\
\hline D44 & Navicula omissa & & + & \\
\hline $\mathrm{D} 45$ & Navicula perrostrata & + & & \\
\hline D46 & Navicula disjuncta & + & & \\
\hline D47 & Navicula disjuncta f. anglica & + & & \\
\hline D48 & Navicula minuscula & + & + & \\
\hline D49 & Navicula placentula & + & & \\
\hline D50 & Navicula asellus & + & & \\
\hline D51 & Navicula dicephala & + & & \\
\hline D52 & Navicula lenzii & + & & \\
\hline
\end{tabular}


Table A1. Cont.

\begin{tabular}{|c|c|c|c|c|}
\hline ID & Species & $\mathbf{W}$ & $\mathbf{J}$ & BL \\
\hline D53 & Navicula rotaenea & + & & \\
\hline D54 & Navicula virihensis & + & + & \\
\hline D55 & Navicula hasta Pantocsek & + & & \\
\hline D56 & Navicula protracta & + & & \\
\hline D57 & Navicula protracta var. elliptica & + & & \\
\hline D58 & Navicula adversa & + & & \\
\hline D59 & Navicula tuscula & + & + & + \\
\hline D60 & Navicula atomus & & + & + \\
\hline D61 & Navicula permitis & + & + & + \\
\hline D62 & Navicula nivaloides & & + & \\
\hline D63 & Navicula virihensis & & + & \\
\hline D64 & Navicula virihensis & + & & \\
\hline D65 & Pinnularia appendiculata var. budensis & + & + & + \\
\hline D66 & Pinnularia molaris & & + & + \\
\hline D67 & Pinnularia bogotensis & + & & \\
\hline D68 & Hantzschia amphioxys & + & & + \\
\hline D69 & Hantzschia amphioxys var. aequalis & + & & \\
\hline D70 & Meridion circulare & + & & + \\
\hline D71 & Nitzschia obtusa var. scalpelliformis & & & + \\
\hline D72 & Nitzschia palea & + & + & + \\
\hline D73 & Nitzschia acicularis & + & + & + \\
\hline D74 & Nitzschia hantzschiana & + & & \\
\hline D75 & Nitzschia frustulum & + & + & \\
\hline D76 & Nitzschia frustulum var. perpusilla & & & + \\
\hline D77 & Nitzschia frustulum var. perminuta & + & & \\
\hline D78 & Nitzschia frustulum var. subsalina & + & + & + \\
\hline D79 & Nitzschia recta & + & + & + \\
\hline D80 & Nitzschia dissipata & + & + & + \\
\hline D81 & Nitischia constricta & + & + & + \\
\hline D82 & Nitzschia hungarica & + & & + \\
\hline D83 & Nitzschia sigmoides & + & + & \\
\hline D84 & Nitzschia linearis & + & + & + \\
\hline D85 & Nitzschia microcephala & + & + & + \\
\hline D86 & Nitzschia heuflerana & + & & \\
\hline D87 & Nitzschia stagnorum & + & & + \\
\hline D88 & Nitzschia fonticola & + & + & + \\
\hline D89 & Nitzschia ovalis & & + & + \\
\hline D90 & Nitzschia paleacea & & & + \\
\hline D91 & Nitzschia & + & + & + \\
\hline D92 & Nitzschia thermalis & & & + \\
\hline D93 & Nitzschia tryblionella var. victorise & + & + & + \\
\hline D94 & Nitzschia tryblionella var. levidensis & + & & \\
\hline D95 & Nitzschia commutata & & + & \\
\hline D96 & Nitzschia acula & + & + & \\
\hline D97 & Nitzschia debilis & + & & + \\
\hline D98 & Nitzschia actinastroides & + & & \\
\hline D99 & Nitzschia communis var. abbreviata & + & + & \\
\hline D100 & Nitzschia heidenii & + & + & \\
\hline D101 & Nitzschia angustata var. acuta & + & & \\
\hline D102 & Nitzschia kuetzingiana & + & & \\
\hline D103 & Nitzschia sinuata var. tabellaria & + & + & + \\
\hline D104 & Nitzschia gracilis & + & + & + \\
\hline D105 & Nitzschia romana & + & & \\
\hline D106 & Nitzschia amphbia & + & + & \\
\hline D107 & Nitzschia clausi & & + & \\
\hline D108 & Nitzschia sublinearis & & + & \\
\hline D109 & Stauroneis anceps & & & + \\
\hline D110 & Stauroneis anceps var. linearis & & & + \\
\hline
\end{tabular}


Table A1. Cont.

\begin{tabular}{|c|c|c|c|c|}
\hline ID & Species & $\mathbf{W}$ & $\mathbf{J}$ & BL \\
\hline D111 & Stauroneis schroederi & & + & + \\
\hline D112 & Stauroneis dubitabilis & + & & \\
\hline D113 & Stauroneis kriegeri & + & & \\
\hline D114 & Stauroneis palustris & + & & \\
\hline D115 & Rhoicosphenia curvata & + & + & \\
\hline D116 & Amphora ovalis & + & + & + \\
\hline D117 & Amphora ovalis var. gracilis & + & + & + \\
\hline D118 & Amphora perpusilla & + & + & \\
\hline D119 & Cymbella ehrenbergii & + & + & + \\
\hline D120 & Cymbella sinnata & + & + & + \\
\hline D121 & Cymbella microcephala & + & + & + \\
\hline D122 & Cymbella pusilla & + & + & + \\
\hline D123 & Cymbella cistula & + & + & + \\
\hline D124 & Cymbella cistula var. maculata & + & & + \\
\hline D125 & Cymbella cistula var. caldostagnensis & + & & \\
\hline D126 & Encyonema ventricosum & + & + & + \\
\hline D127 & Cymbella ventricosa var. simicircularis & + & & + \\
\hline D128 & Cymbella amphicephala & + & + & + \\
\hline D129 & Cymbella amphicephala var. intermedia & + & & \\
\hline D130 & Cymbella aequalis & + & + & + \\
\hline D131 & Cymbella tumidula & + & & + \\
\hline D132 & Cymbella turgida & + & + & + \\
\hline D133 & Cymbella turgidula & & & + \\
\hline D134 & Cymbella aequalis & + & & \\
\hline D135 & Cymbella aequalis var. pisciculus & + & + & + \\
\hline D136 & Cymbella prostrata & + & + & + \\
\hline D137 & Cymbella gaeumanni & + & & + \\
\hline D138 & Cymbella sphaerophora & + & + & + \\
\hline D139 & Cymbella cymbiformis & + & + & + \\
\hline D140 & Cymbella perpusilla & + & + & \\
\hline D141 & Cymbella bremii & + & + & \\
\hline D142 & Cymbella lata & + & + & \\
\hline D143 & Cymbella gracilis & + & & \\
\hline D144 & Cymbella lunata & + & & \\
\hline D145 & Cymbella excisa & + & & \\
\hline D146 & Cymbella alpina var. minuta & + & & \\
\hline D147 & Cymbella lapponica & + & & \\
\hline D148 & Cymbella aspera & + & & \\
\hline D149 & Cymbella hustedtii & + & + & \\
\hline D150 & Cymbella jolmolungnensis & + & & \\
\hline D151 & Cymbella hauckii & + & & \\
\hline D152 & Cymbella parva & + & & \\
\hline D153 & Cymbella hybrida & + & + & + \\
\hline D154 & Cymbella helvatica & + & & \\
\hline D155 & Diatoma vulgare & + & + & + \\
\hline D156 & Diatoma vulgare var. lineare & + & + & + \\
\hline D157 & Diatoma vulgare var. producta & + & + & + \\
\hline D158 & Diatoma anceps & + & & \\
\hline D159 & Diatoma elongata & & & + \\
\hline D160 & Diatoma elongata var. tenuis & + & + & + \\
\hline D161 & Diatoma hiemale & & & \\
\hline D162 & Gomphonema paroulum & + & + & + \\
\hline D163 & Gomphonema parvulum var. subellipticum & + & + & + \\
\hline D164 & Gomphonema parvulum var. exilissima & + & & + \\
\hline D165 & Gomphonema angustatum & + & + & + \\
\hline D166 & Gomphonema angustatum var. aequalis & + & & \\
\hline D167 & Gomphonema intricatum & + & + & + \\
\hline D168 & $\begin{array}{c}\text { Gomphonema intricatum var. } \\
\text { dichotomiformis }\end{array}$ & + & + & + \\
\hline
\end{tabular}


Table A1. Cont.

\begin{tabular}{|c|c|c|c|c|}
\hline ID & Species & $\mathbf{W}$ & $\mathbf{J}$ & BL \\
\hline D169 & Gomphonema olivaceum & + & + & + \\
\hline D170 & Gomphonema olivaceum var. minutissima & & & + \\
\hline D171 & Gomphonema turris & + & & \\
\hline D172 & Gomphonema gracile & + & + & + \\
\hline D173 & Gomphonema gracile var. intricatiformis & & + & + \\
\hline D174 & Gomphonema constrictum & + & + & + \\
\hline D175 & Gomphonema montanum & + & + & \\
\hline D176 & Gomphonema sphaerophorum & + & + & + \\
\hline D177 & Gomphonema & + & & \\
\hline D178 & Gomphonema tergestium & + & & \\
\hline D179 & Achnanthes lanceolata & + & & \\
\hline D180 & Achnanthes lanceolata $f$. ventricosa & + & + & + \\
\hline D181 & Achnanthes linearis & + & & + \\
\hline D182 & Achnanthidium minutissimum & + & + & + \\
\hline D183 & $\begin{array}{l}\text { Achnanthidium minutissimum var. } \\
\text { cryptocephala }\end{array}$ & + & + & + \\
\hline D184 & Achnanthes amphicephala & + & & + \\
\hline D185 & Achnanthes hauckiana & + & + & + \\
\hline D186 & Achnanthes tibetica & & & + \\
\hline D187 & Achnanthes affinis & + & + & + \\
\hline D188 & Achnanthes delicatula & + & & + \\
\hline D189 & Achnanthes montana & + & + & + \\
\hline D190 & Achnanthes crassa & + & + & + \\
\hline D191 & Achnanthes exilis & & & + \\
\hline D192 & Achnanthes subhudsonis & + & & \\
\hline D193 & Achnanthes conspicua & + & & \\
\hline D194 & Achnanthes clevei & + & & \\
\hline D195 & Achnanthes nodosa & + & & \\
\hline D196 & Achnanthes microcephala & + & + & \\
\hline D197 & Cocconeis pediculus & + & + & + \\
\hline D198 & Cocconeis placentula & + & + & + \\
\hline D199 & Fragilaria capucina & & + & + \\
\hline D200 & Fragilaria capucina var. mesolepta & & + & \\
\hline D201 & Fragilaria var. subsalina & + & + & + \\
\hline D202 & Fragilaria ungeriana & & & + \\
\hline D203 & Fragilaria intermedia & + & & \\
\hline D204 & Fragilaria vaucheriae var. capitellata & + & & \\
\hline D205 & Fragilaria virescens var. mesolepta & + & & \\
\hline D206 & Synedra acus & + & + & \\
\hline D207 & Synedra acus var. radians & & & + \\
\hline D208 & Synedra ulna & + & + & + \\
\hline D209 & Synedra ulna var. danica & + & + & + \\
\hline D210 & Synedra ulna var. contracta & + & + & + \\
\hline D211 & Synedra ulna var. oxyrhnchus & + & + & \\
\hline D212 & Synedra amphicephala & + & & \\
\hline D213 & Surirella subsalsa & + & & \\
\hline D214 & Surirella tibetica & + & + & + \\
\hline D215 & Surirella ovalis & & & + \\
\hline D216 & Surirella ovalis var. salina & + & + & + \\
\hline D217 & S.brebissonii & + & + & + \\
\hline D218 & Surirella & + & & \\
\hline D219 & Surirella robusta & + & & \\
\hline $\mathrm{D} 220$ & Surirella capronii & + & & \\
\hline D221 & Surirella angusta & + & + & \\
\hline D222 & Cyclotella stelligera & + & + & + \\
\hline D223 & Cyclotella meneghiniana & + & + & + \\
\hline D224 & Cyclotella kuetzingiana & + & + & + \\
\hline D225 & Pantocsekiella ocellata & + & + & + \\
\hline
\end{tabular}


Table A1. Cont.

\begin{tabular}{|c|c|c|c|c|}
\hline ID & Species & $\mathbf{W}$ & $\mathbf{J}$ & BL \\
\hline D226 & Cyclotella catenata & + & + & + \\
\hline D227 & Cyclotella asterocostata & + & & \\
\hline D228 & Gyrosigma scalproides & + & + & + \\
\hline D229 & Gyrosigma acuminatum & & + & + \\
\hline D230 & Gyrosigma attenuatum & & & + \\
\hline D231 & Gyrosigma kuetzingii & + & + & + \\
\hline D232 & Cymatopleuta solea & + & + & \\
\hline D233 & Diploneis elliptica & & & + \\
\hline D234 & Diploneis ovalis & + & & + \\
\hline D235 & Diploneis pseudovalis & + & & \\
\hline D236 & Neidium kozlowi var. elliptica & & & + \\
\hline D237 & Neidium iridis var. ampliatum & & & + \\
\hline D238 & Stephanodiscus minutulus & & & + \\
\hline D239 & Ceratoneis arcus & + & + & + \\
\hline D240 & Ceratoneis arcus var. linearis & + & + & + \\
\hline D241 & Ceratoneis arcus var. linearis f.recta & & & + \\
\hline D242 & Ceratoneis arcus var. amphioxys & & + & \\
\hline $\mathrm{D} 243$ & Caloneis alpestris var. lanceolata & & + & \\
\hline D244 & Caloneis bacilaria & + & & \\
\hline D245 & Caloneis amphisbaena & & + & \\
\hline D246 & Amphiraphia xizangensis & + & & \\
\hline D247 & Rhopalodia gibba & + & & \\
\hline D248 & Amphipleura pellucida & & + & + \\
\hline D249 & Didymosphenia geminata & + & & \\
\hline $\mathrm{D} 250$ & Denticula elegans & + & & \\
\hline D251 & Frustulia vulgaris & + & & \\
\hline
\end{tabular}

Appendix B. The Distribution of Macroinvertebrate Assemblage in the W, J, and BL Catchments

Table A2. The list of macroinvertebrate species in Wei River basin.

\begin{tabular}{ccccc}
\hline ID & Species & W & J & BL \\
\hline B1 & Baetidae Analetridae & + & + & + \\
B2 & Baetis vaillanti & + & + & + \\
B3 & Serratellasp. & + & + & + \\
B4 & Leptophlebiasp. & + & + & + \\
B5 & Cinygmasp. & + & + & \\
B6 & Polymitarcyidae & + & & \\
B7 & Epeorsu curvispinosa & + & & \\
B8 & Chromarcyssp. & + & & \\
B9 & Ephemera nigroptera & + & & \\
B10 & Osobenussp. & + & + & \\
B11 & Hydropsychesp. & + & + & \\
B12 & Brunnea larva & & & \\
B13 & Dolophilodes sp. & + & & \\
B14 & Austrotinodessp. & + & & \\
B15 & Tipulasp. & + & & \\
B16 & Antochasp. & + & & + \\
B17 & Tabanussp. & + & + \\
B18 & Natarsia punctata & & \\
B19 & Ablabesmyia phatta & & & \\
B20 & Procladius choreus & + & \\
B21 & Conchapelopia sp. & + & + \\
B22 & Polypedilum scalaenum & + & \\
\hline
\end{tabular}


Table A2. Cont.

\begin{tabular}{|c|c|c|c|c|}
\hline ID & Species & $\mathbf{W}$ & $\mathbf{J}$ & BL \\
\hline B23 & Procladius paradouxus & + & & \\
\hline B24 & Orthocaladius mixtus & + & & \\
\hline B25 & Orthocladius makabensis Sasa & + & & + \\
\hline B26 & Cricotopus albiforceps & & & + \\
\hline B27 & Cricotopus trifasciatus & + & + & + \\
\hline B28 & Cricotopus triannulatus & + & + & + \\
\hline B29 & Cricotopus bicinctus & + & + & \\
\hline B30 & Paracricotopus sp. & + & + & \\
\hline B31 & Cricotopus anulator Goetghebuer & + & & \\
\hline B32 & Diplocladius Kieffer & + & & \\
\hline B33 & Rheocricotopus fuscipes & & + & + \\
\hline B34 & Rheocricotopus effuses & + & & \\
\hline B35 & Paratrichocladius rufivertris & & & + \\
\hline B36 & Rheotanytarsus sp. & + & & \\
\hline B37 & Chironomus riparius Meigen & + & + & + \\
\hline B38 & Chironomus salinarius Kiffer & + & & + \\
\hline B39 & Thienmanniola sp. & + & + & + \\
\hline B40 & Chironomus sp. & + & + & + \\
\hline B41 & Polypedilum paraviceps Niitsuma & + & & + \\
\hline B42 & Micropesectra atrofasciata & + & & + \\
\hline B43 & Cyphomella cornea & + & & \\
\hline B44 & Antocha bifida Alexander & & & + \\
\hline B45 & Sympotthastia takatensis & + & & \\
\hline B46 & Lappodiamesa sp. & + & + & \\
\hline B47 & Simuliumsp. & + & + & + \\
\hline B48 & Sciomyzidae sp. & + & + & \\
\hline B49 & Psychodasp. & + & + & + \\
\hline B50 & Liodessussp. & + & & \\
\hline B51 & Hydrous sp. & + & & \\
\hline B52 & Stenelmis sp adult & + & + & + \\
\hline B53 & Gomphussp. & + & + & \\
\hline B54 & Gomphidae sp. & + & & + \\
\hline B55 & Aeschna sp. & & & + \\
\hline B56 & Pontamalota sp. & + & & \\
\hline B57 & Epitheca.marginata & & & \\
\hline B58 & Radix clessini & + & + & \\
\hline B59 & Radix ovata & + & + & + \\
\hline B60 & physa acuta cf. & + & & + \\
\hline B61 & Polypylis hemisphaerula & & + & + \\
\hline B62 & Bellamya aeruginosa & + & & \\
\hline B63 & Schistodesmus lampreyanus & + & & + \\
\hline B64 & Limnodrilus hoffmeisteri & + & + & + \\
\hline B65 & Branchiura sowerbyi & + & & \\
\hline B66 & Limnodrilus claparedianus & + & & + \\
\hline B67 & Tubifex sinicus & + & & + \\
\hline B68 & Whitmania pigra & + & & \\
\hline B69 & Barbronia weberi & + & & \\
\hline B70 & Gammarussp. & + & + & \\
\hline B71 & Sinopotamidae.sp & + & & + \\
\hline B72 & Exopalaemon modestus & + & + & \\
\hline B73 & Macrobrachium nipponense de Haan & + & & \\
\hline
\end{tabular}




\section{Appendix C. The Distribution of Fish Assemblage in the W, J, and BL Catchments}

Table A3. The list of fish species in Wei River basin.

\begin{tabular}{|c|c|c|c|c|}
\hline ID & Species & $\mathbf{W}$ & $\mathbf{J}$ & BL \\
\hline $\mathrm{F} 1$ & Protosalanx hyalocranius & + & & \\
\hline $\mathrm{F} 2$ & Paracobitis variegates & + & & \\
\hline F3 & Triplophysa dalaica & + & + & + \\
\hline $\mathrm{F} 4$ & Triplophysa sellaefer & + & + & + \\
\hline F5 & Triplophysa shaanxiensis & + & + & + \\
\hline F6 & Triphysa stoliczkae & + & + & + \\
\hline F7 & Triplopphysa bleekeri & + & + & + \\
\hline F8 & Triplophysa robusta & + & + & + \\
\hline F9 & Triplophysa stoliczkae dorsonotata & + & + & + \\
\hline F10 & Triplophysa kungessana orientalis & + & + & \\
\hline F11 & Triplophysa pappenheimi & + & + & + \\
\hline F12 & Triplophysa sp. & + & & \\
\hline F13 & Botia superciliaris & + & & \\
\hline F14 & Cobitis granoei & + & & \\
\hline F15 & Misgurnus anguillicaudatus & + & + & + \\
\hline F16 & Paramisgurnus dabryyanus & & + & + \\
\hline F17 & Opasariichthys bidens & + & + & + \\
\hline F18 & Brachymystax lenok & + & & \\
\hline F19 & Phoxinus lagowskii & + & + & + \\
\hline F20 & Rhodeus sinensis & + & & + \\
\hline F21 & Rhoaeus lighti & + & + & + \\
\hline F22 & Hemiculter leucisculus & + & & + \\
\hline F23 & Belligobio nummifer & + & & + \\
\hline F24 & Oryzias latipes & + & & + \\
\hline F25 & Pseudorasbora parva & + & + & + \\
\hline F26 & Gnathopogon imberbis & + & & + \\
\hline $\mathrm{F} 27$ & Huigobio chinssuensis & + & & \\
\hline F28 & Gobio rivuloides & + & & \\
\hline F29 & Abbottina rivularis & + & + & + \\
\hline F30 & Sarcocheilichthys nigripinnis & + & & \\
\hline F31 & Huigobio chinssuensis & + & + & + \\
\hline F32 & Scaphesthes macrolepis & + & & \\
\hline F33 & Gymnodiptychus pachycheilus weiheensis & + & & \\
\hline F34 & Schizopygopsis pylzovi & + & & \\
\hline F35 & Cyprinus carpio & + & & \\
\hline F36 & Carassius auratus & + & + & + \\
\hline F37 & Silurus asotus & + & + & + \\
\hline F38 & Pelteobagrus nitidus & + & & \\
\hline F39 & Hypseleotris swinhonis & + & & + \\
\hline $\mathrm{F} 40$ & Ctenogobius cliffordpopei & + & + & + \\
\hline F41 & Ctenogobius brunneus & + & + & + \\
\hline F42 & Ctenogobius gymnauchen & + & & + \\
\hline F43 & Ctenogobius shennongensis & + & & + \\
\hline F44 & Ctenogobius giurinus & + & & + \\
\hline F45 & Channa argus & + & & \\
\hline
\end{tabular}

\section{References}

1. Cooper, S.D.; Lake, P.S.; Sabater, S.; Melack, J.M.; Sabo, J.L. The effects of land use changes on streams and rivers in mediterranean climates. Hydrobiologia 2013, 719, 383-425. [CrossRef]

2. Kratzer, B.E.; Jackson, J.K.; Arscott, D.B.; Aufdenkampe, A.K.; Dow, C.L. Macroinvertebrate distribution in relation to land use and water chemistry in New York City drinking-water-supply watersheds. J. N. Am. Benthol. Soc. 2009, 25, 954-976. [CrossRef] 
3. Spnseller, R.A.; Benfield, E.F.; Valett, H.M. Relationships between land use, spatial scale and stream macroinvertebrate communities. Freshw. Biol. 2001, 46, 1409-1424. [CrossRef]

4. Vázquez, G.; Aké-Castillo, J.A.; Favila, M.E. Algal assemblages and their relationship with water quality in tropical Mexican streams with different land uses. Hydrobiologia 2011, 667, 173-189. [CrossRef]

5. Dahm, V.; Hering, D.; Nemitz, D.; Graf, W.; Schmidt-Kloiber, A.; Leitner, P.; Melcher, A.; Feld, C.K. Effects of physico-chemistry, land use and hydromorphology on three riverine organism groups: A comparative analysis with monitoring data from Germany and Austria. Hydrobiologia 2013, 704, 389-415. [CrossRef]

6. Miserendino, M.L.; Casaux, R.; Archangelsky, M.; di Prinzio, C.Y.; Brand, C.; Kutschker, A.M. Assessing land-use effects on water quality, in-stream habitat, riparian ecosystems and biodiversity in Patagonian northwest streams. Sci. Total Environ. 2011, 409, 612-624. [CrossRef]

7. Villeneuve, B.; Souchon, Y.; Usseglio-Polatera, P.; Ferréol, M.; Valette, L. Can we predict biological condition of stream ecosystems? A multi-stressors approach linking three biological indices to physico-chemistry, hydromorphology and land use. Ecol. Indic. 2015, 48, 88-98. [CrossRef]

8. Feld, C.K. Response of three lotic assemblages to riparian and catchment-scale land use: Implications for designing catchment monitoring programmes. Freshw. Biol. 2013, 58, 715-729. [CrossRef]

9. Nerbonne, B.A.; Vondracek, B. Effects of local land use on physical habitat, benthic macroinvertebrates, and fish in the Whitewater River, Minnesota, USA. Environ. Manag. 2001, 28, 87-99. [CrossRef]

10. Theodoropoulos, C.; Aspridis, D.; Iliopoulou-Georgudaki, J. The influence of land use on freshwater macroinvertebrates in a regulated and temporary Mediterranean river network. Hydrobiologia 2015, 751, 201-213. [CrossRef]

11. Booth, D.B.; Karr, J.R.; Schauman, S.; Konrad, C.P.; Morley, S.A.; Larson, M.G.; Burges, S.J. Reviving urban streams: Land use, hydrology, biology, and human behavior. J. Am. Water Resour. Assoc. 2004, 40, 1351-1364. [CrossRef]

12. Ding, J.; Jiang, Y.; Liu, Q.; Hou, Z.; Liao, J.; Fu, L.; Peng, Q. Influences of the land use pattern on water quality in low-order streams of the Dongjiang River basin, China: A multi-scale analysis. Sci. Total Environ. 2016, 551-552, 205-216. [CrossRef] [PubMed]

13. Castello, L.; Macedo, M.N. Large-scale degradation of Amazonian freshwater ecosystems. Glob. Chang. Biol. 2016, 22, 990-1007. [CrossRef] [PubMed]

14. Tong, S.T.Y.; Chen, W. Modeling the relationship between land use and surface water quality. J. Environ. Manag. 2002, 66, 377-393. [CrossRef] [PubMed]

15. Aparicio, E.; Carmona-Catot, G.; Moyle, P.B.; García-Berthou, E. Development and evaluation of a fish-based index to assess biological integrity of Mediterranean streams. Aquat. Conserv. Mar. Freshw. Ecosyst. 2011, 21, 324-337. [CrossRef]

16. Tan, X.; Ma, P.; Bunn, S.E.; Zhang, Q. Development of a benthic diatom index of biotic integrity (BD-IBI) for ecosystem health assessment of human dominant subtropical rivers, China. J. Environ. Manag. 2015, 151, 286-294. [CrossRef]

17. Van Ael, E.; de Cooman, W.; Blust, R.; Bervoets, L. Use of a macroinvertebrate based biotic index to estimate critical metal concentrations for good ecological water quality. Chemosphere 2015, 119, 138-144. [CrossRef]

18. Almeida, D.; Alcaraz-Hernández, J.D.; Merciai, R.; Benejam, L.; García-Berthou, E. Relationship of fish indices with sampling effort and land use change in a large Mediterranean river. Sci. Total Environ. 2017, 605-606, 1055-1063. [CrossRef]

19. Urbanič, G.; Mihaljević, Z.; Petkovska, V.; Pavlin Urbanić, M. Disentangling the effects of multiple stressors on large rivers using benthic invertebrates-A study of Southeastern European large rivers with implications for management. Water 2020, 12, 621. [CrossRef]

20. Wang, H.L.; Wan, A.; Zhang, X.K. The effect of land use type on the macroinvertebrate assemblage in Wannan mountain area, China. J. Suzhou Univ. 2015, 30, 110-113.

21. Li, J.L.; Jin, W.; Wang, B.H.; Xiang, Z.L.; Yin, X.W.; Xu, Z.X.; Zhang, Y. Relationship between land use types within riparian zones and community structure of diatom in Taizi River, China. Res. Environ. Sci. 2015, 28, 1662-1669.

22. Wu, W.; Xu, Z.; Kennard, M.J.; Yin, X.; Zuo, D. Do human disturbance variables influence more on fish community structure and function than natural variables in the Wei River basin, China? Ecol. Indic. 2016, 61, 438-446. [CrossRef] 
23. Yu, S.; Xu, Z.; Wu, W.; Zuo, D. Effect of land use types on stream water quality under seasonal variation and topographic characteristics in the Wei River basin, China. Ecol. Indic. 2016, 60, 202-212. [CrossRef]

24. Zuo, D.; Xu, Z.; Wu, W.; Zhao, J.; Zhao, F. Identification of Streamflow Response to Climate Change and Human Activities in the Wei River Basin, China. Water Resour. Manag. 2014, 28, 833-851. [CrossRef]

25. Zuo, D.; Xu, Z.; Peng, D.; Song, J.; Cheng, L.; Wei, S.; Abbaspour, K.C.; Yang, H. Simulating spatiotemporal variability of blue and green water resources availability with uncertainty analysis. Hydrol. Process. 2015, 29, 1942-1955. [CrossRef]

26. Mangadze, T.; Bere, T.; Mwedzi, T. Choice of biota in stream assessment and monitoring programs in tropical streams: A comparison of diatoms, macroinvertebrates and fish. Ecol. Indic. 2016, 63, 128-143. [CrossRef]

27. Lin, G.Y. Fauna Sinica: Phylum Mollusca, Class Gastropoda, Subclass Opisthobranchia, Order Cephalaspidea; Science Press: Beijing, China, 1997.

28. Wang, J.C.; Wang, X.H. Chironomus Larvae in Northern China; China Yan Shi Press: Beijing, China, 2011.

29. Yang, T. Fauna Sinica: Annelida, Hirudinea; Science Press: Beijing, China, 2002.

30. Hu, H.J.; Wei, Y.X. The Freshwater Algae of China: Systematics, Taxonomy and Ecology; Science Press: Beijing, China, 2006.

31. Zhu, H.Z.; Chen, J.Y. China Tibet Diatoms; Science Press: Beijing, China, 2000.

32. Barbour, M.T.; Gerritsen, J.; Snyder, B.D.; Stribling, J.B. Rapid Bioassessment Protocols for Use in Streams and Wadeable Rivers: Periphyton, Benthic Macroinvertebrates and Fish; US Environmental Protection Agency, Office of Water: Washington, DC, USA, 1999.

33. Wu, Z.; Wang, X.; Chen, Y.; Cai, Y.; Deng, J. Assessing river water quality using water quality index in Lake Taihu Basin, China. Sci. Total Environ. 2018, 612, 914-922. [CrossRef]

34. Fonseca, D.G.; Tanaka, M.O. Influence of an exotic grass on benthic macroinvertebrate communities in a tropical rural landscape. Hydrobiologia 2015, 762, 239-251. [CrossRef]

35. Hlúbiková, D.; Novais, M.H.; Dohet, A.; Hoffmann, L.; Ector, L. Effect of riparian vegetation on diatom assemblages in headwater streams under different land uses. Sci. Total Environ. 2014, 475, 234-247. [CrossRef]

36. Longyang, Q. Assessing the effects of climate change on water quality of plateau deep-water lake-A study case of Hongfeng Lake. Sci. Total Environ. 2019, 647, 1518-1530. [CrossRef]

37. Pardo, I.; Delgado, C.; Abraín, R.; Gómez-Rodríguez, C.; García-Roselló, E.; García, L.; Reynoldson, T.B. Apredictive diatom-based model to assess the ecological status of streams and rivers of Northern Spain. Ecol. Indic. 2018, 90, 519-528. [CrossRef]

38. Petersen, C.R.; Jovanovic, N.Z.; Grenfell, M.C.; Oberholster, P.J.; Cheng, P. Responses of aquatic communities to physical and chemical parameters in agriculturally impacted coastal river systems. Hydrobiologia 2018, 813, 157-175. [CrossRef]

39. Shen, R.; Ren, H.; Yu, P.; You, Q.; Pang, W.; Wang, Q. Benthic Diatoms of the Ying River (Huaihe River Basin, China) and Their Application in Water Trophic Status Assessment. Water 2018, 10, 1013. [CrossRef]

40. Wang, L.; Pan, Y.; Cao, Y.; Li, B.; Wang, Q.; Wang, B.; Pang, W.; Zhang, J.; Zhu, Z.; Deng, G. Detecting early signs of environmental degradation in protected areas: An example of Jiuzhaigou Nature Reserve, China. Ecol. Indic. 2018, 91, 287-298. [CrossRef]

41. Szczepocka, E.; Krawczyk, P.N.; Kruk, A. Deceptive ecological status of urban streams and rivers-evidence from diatom indices. Ecosphere 2018, 9, e02310. [CrossRef]

42. Zhang, Y.; Cheng, L.; Tolonen, K.E.; Yin, H.; Gao, J.; Zhang, Z.; Li, K.; Cai, Y. Substrate degradation and nutrient enrichment structuring macroinvertebrate assemblages in agriculturally dominated Lake Chaohu Basins, China. Sci. Total Environ. 2018, 627, 57-66. [CrossRef]

43. Maceda-Veiga, A.; Nally, R.M.; de Sostoa, A. Water-quality impacts in semi-arid regions: Can natural 'green filters' mitigate adverse effects on fish assemblages? Water Res. 2018, 144, 628-641. [CrossRef]

44. Maceda-Veiga, A.; Nally, R.M.; de Sostoa, A. Environmental correlates of food-chain length, mean trophic level and trophic level variance in invaded riverine fish assemblages. Sci. Total Environ. 2018, 644, 420-429. [CrossRef]

45. Delgado, C.; Pardo, I. Comparison of benthic diatoms from Mediterranean and Atlantic Spanish streams: Community changes in relation to environmental factors. Aquat. Bot. 2015, 120, 304-314. [CrossRef]

46. Meador, M.R.; Frey, J.W. Relative Importance of Water-Quality Stressors in Predicting Fish Community Responses in Midwestern Streams. J. Am. Water Resour. Assoc. 2018, 54, 708-723. [CrossRef] 
47. Xu, M.; Wang, Z.; Duan, X.; Pan, B. Effects of pollution on macroinvertebrates and water quality bio-assessment. Hydrobiologia 2014, 729, 247-259. [CrossRef]

48. Yoshimura, C.; Tockner, K.; Omura, T.; Moog, O. Species diversity and functional assessment of macroinvertebrate communities in Austrian rivers. Limnology 2006, 7, 63-74. [CrossRef]

49. Zhang, Y.; Liu, L.; Cheng, L.; Cai, Y.; Yin, H.; Gao, J.; Gao, Y. Macroinvertebrate assemblages in streams and rivers of a highly developed region (Lake Taihu Basin, China). Aquat. Biol. 2014, 23, 15-28. [CrossRef]

50. Wu, W.; Xu, Z.X.; Yin, X.W.; Yu, S.Y. Fish community structure and the effect of environmental factors in the Wei River basin. Acta Sci. Circumstantiae 2014, 34, 1298-1308.

Publisher's Note: MDPI stays neutral with regard to jurisdictional claims in published maps and institutional affiliations.

(C) 2020 by the authors. Licensee MDPI, Basel, Switzerland. This article is an open access article distributed under the terms and conditions of the Creative Commons Attribution (CC BY) license (http://creativecommons.org/licenses/by/4.0/). 